\title{
Skapende og tenkende - Kritisk kunstpedagogikk i Freires fotspor
}

[...] the important thing is to educate the curiosity through which knowledge is constituted as it grows and refines itself through the very exercise of knowing (Freire 1997, s. 31)

I 2016 startet forskningsgruppen InOvation ved UiT - Norges arktiske universitet, Musikkonservatoriet, har vi de siste par årene valgt å fordype oss i klassiske tekster fra den kritisk pedagogiske tradisjonen inspirert av pedagogen og filosofen Paulo Freire. Vi ønsket å bidra til en fornyet kritisk kunstpedagogisk tenkning ut fra våre faglige ståsteder. Vår forforståelse er at det i Norge er underbelyst hvordan kritisk kunstpedagogisk tenkning kan bidra inn i en senmoderne forståelse av utdanning. Forskningsgruppen består av musikk- og dramapedagoger ved UiTs forskjellige utøvende og pedagogiske kunstutdanninger, og nettopp den tverrfagligheten dette miljøet representerer, har gitt interessante og nye perspektiver på hva kritisk pedagogikk kan være i de forskjellige fagfeltene. Eksempelvis har kritisk pedagogiske perspektiver fra Freiretradisjonen fått godt feste særlig i drama- og teaterfagene, mens Freires tankegods fremdeles gis lite oppmerksomhet i fag som musikk- og dansepedagogikk og i kunst- og håndverkfaget, noe som gjenspeiles både i fagpedagogisk litteratur og i forskning i disse fagene. I dette temanummeret vil forskning og utviklingsarbeider fra musikk- og dramafaget bli presentert og drøftet, med mål om å gi et bidrag til den norske diskusjonen om fornyet relevans av kritisk pedagogikk i kunstfagene. Artiklene initierer en kunstpedagogisk debatt i norsk kontekst ved både å konkretisere og eksemplifisere hvordan kritiske pedagogiske perspektiver kan få betydning for utdanningenes utvikling, og også ved å vende et kritisk blikk innover egne utdanninger.

Selv om det er mange referanser til nordisk pedagogisk litteratur i dette temanummeret, er det i stor grad stemmene fra nord- og latinamerikansk kritisk pedagogikk som har gitt gjenklang hos forfatterne. Navn som Giroux, hooks, Darder og Kincheloe er referansepunkter. Mest sentralt står imidlertid Paolo Freire, som var opphavsperson til den nyere kritiske pedagogikken. Han representerer en pedagogisk

^Korrespondanse: Michael Strobelt, UiT Norges arktiske universitet, Postboks 6050 Langnes, 9037 Tromsø. Epost: Michael.strobelt@uit.no

(C) 2018 H. Blix. This is an Open Access article distributed under the terms of the Creative Commons Attribution 4.0 International License (https://creativecommons.org/licenses/by-nc/4.0/), allowing third parties to copy and redistribute the material in any medium or format and to remix, transform, and build upon the material for any purpose, even commercially, provided the original work is properly cited and states its license.

Citation: H. Blix. «Skapende og tenkende - Kritisk kunstpedagogikk i Freires fotspor». Fournal for Research in Arts and Sports Education, Special Issue: «Skapende og tenkende - Perspektiver på kritisk kunstpedagogikk i skole og kulturliv» Vol. 2(2), 2018, pp. 1-3. http://dx.doi.org/10.23865/jased.v2.929 
retning med sosial og politisk transformasjon som hovedanliggende, hvor pedagogikk og utdanning skal ta de svakes side og vekke bevissthet om urettferdighet og asymmetriske maktforhold. Vi ønsker å bidra til en debatt om disse ideenes berettigelse i kunstfaglig utdanning i det nordiske pedagogiske landskapet. Sentrale begreper som diskuteres i artiklene er kritisk bevisstgjøring - conscientização (Freire 1968), transformasjon, makt og empowerment (myndiggjørelse), i tillegg til spørsmål om dialog og deltakelse.

De store og raske endringene i det politiske og sosiale klimaet i Europa og andre deler av verden gjør det nødvendig å stille spørsmålet om hvordan vi ivaretar felles verdier og et inkluderende samfunn. Fremveksten av populistiske og autoritære politiske krefter, økologiske trusler og en økende sosio-økonomisk ulikhet tydeliggjør at man i dag i økende grad må betrakte skole og utdanning som en arena for positiv samfunnsendring. Det er utfordrende å forberede den kommende generasjonen til et menings- og ansvarsfullt liv, noe som også understrekes i Ludvigsenutvalgets utredning om Fremtidens skole, der utvalget også trekker fram hvordan estetiske fag, med sine utforskende arbeidsmåter, kan bidra til refleksjon over det samfunnet vi lever $\mathrm{i}$ (NOU 2015: 8, s. 60). Gjennom eksempler, undersøkelser og erfaringer med kritisk kunstpedagogikk diskuterer flere av forfatterne i dette temanummeret hva tankegods fra en Freire-inspirert kritisk pedagogikk kan innebære for kunstfagene i skole og kulturliv. I tillegg undersøkes det hvordan kunstfagene har potensial til å utvikle en persons kritiske bevissthet, kreativitet, empowerment og opplevelse av mening.

Framtidens kunstpedagoger i fag som musikk, drama, dans, litteratur, kunst og håndverk og medie- og designfag behøver verktøy og kunnskap som gjør dem i stand til å bruke sin kreativitet og sitt engasjement i arbeidet med å inspirere neste generasjon samfunnsborgere. Hvis man skal ta på alvor målsettinger om «å utvide barns, unges og voksnes evner til erkjennelse og opplevelse, til innlevelse, utfoldelse og deltakelse» ${ }^{1}$, må man spørre seg hvordan man kan sette studenter og elever i stand til å gjøre seg opp egne meninger og innta en kritisk reflekterende holdning til det lokale og globale samfunnet vi lever og virker i. På et overordnet nivå berører dette temanummeret således også kunstfagenes situasjon og status under en nyliberal utdanningspolitikk.

Den idéhistoriske og teoretiske bakgrunnen til dette temanummeret presenteres i den innledende artikkelen, hvor Strobelt tegner opp hovedlinjene i utviklingen av kritisk pedagogikk og drøfter spørsmålet om hva denne pedagogiske retningen kan bidra med i dagens kunstpedagogikk. Denne artikkelen har funksjon som en posisjoneringsartikkel.

Mittner undersøker, gjennom et konkret kasus, hvordan undervisning i kritisk tenkning gir elever kraft til å gå inn i prosesser for å påvirke innholdet i læreplaner. Blix kaster et kritisk øye på tradisjonelle og nyere instrumentalskoler for barn, og Tollefsen og Blix diskuterer digitale læringsressurser i hørelæreundervisning. Artiklene ser spesielt på hvordan læremidler og eksamensrepertoar representerer sterke

\footnotetext{
${ }^{1}$ Kunnskapsløftet, læreplan for grunnskolen, generell del. (Kunnskapsdepartementet, 2006)
} 
indikatorer på hva som regnes som kunnskap i et fag, og hvordan elever/studenter kan «frigjøre» seg fra læremidlenes/eksamensrepertoarets makt.

Artiklene til Eriksen og Wilhelmsen undersøker dramafagets muligheter til å skape kritisk bevissthet og legge grobunn for transformativ lering. Eriksen beskriver og undersøker erfaringer fra et norsk-russisk samarbeidsprosjekt innen teaterutdanning. Prosjektet er et eksempel på at samarbeid over landegrenser kan være spesielt utfordrende når politiske og kulturelle forskjeller er store, men at teaterfaget gir en unik mulighet til å overkomme hindringer. Artikkelen er relevant for internasjonale samarbeid ut over drama- og teaterfaget, da den peker på aspekter som empowerment, kulturforståelse og Freires tanker om kjærlighet som viktige faktorer for å få et samarbeid til å fungere. Wilhelmsens artikkel handler om å sette i gang utforskende og kritisk refleksjon hos næringslivsledere gjennom praktisk arbeid med bildeteater, en arbeids- og uttrykksmetode som ble utviklet av brasilianeren Augusto Boal og er inspirert av ideene til Paolo Freire. Erfaringene fra dette prosjektet kan ha overføringsverdi til lærerutdanninger, særlig med tanke på skoleledelse og hvordan dramafaglige arbeidsmåter kan bidra til å forstå og utvikle lederrollen.

Jensen problematiserer forholdet og dynamikken mellom lærer og elev i et kritisk pedagogisk perspektiv, og her drøftes betydningsfulle kvaliteter som tålmodighet og gjensidig åpenhet $\mathrm{i}$ den kritiske undervisningsdialogen i sangundervisning. Jensens artikkel er en fagartikkel basert på en praksisfortelling.

Temanummeret viser gjennom eksempler fra musikk- og dramafeltet hvordan kritisk pedagogiske tilnærminger i Norge i dag kan bidra til debatten om kunstfagenes potensielle rolle i dannelsen av kritisk bevisste samfunnsborgere som evner å være endringsagenter i tider hvor både kunnskap og kunst er under press.

Hilde Synnøve Blix, Anne Eriksen og Michael Strobelt

Tromsø, juli 2018

\section{Litteratur}

Freire, P. (1997). Pedagogy of the Heart. New York: Continuum Publishing.

NOU 2015: 8. Fremtidens skole. Fornyelse av fag og kompetanser. Hentet fra: https://www.regjeringen.no/ contentassets/da148fec8c4a4ab88daa8b677a700292/no/pdfs/nou201520150008000dddpdfs.pdf 